\title{
PROBLEM SOLVING DAPAT MENINGKATKAN HASIL BELAJAR SISWA PADA MATERI OPERASI PENJUMLAHAN DAN PENGURANGAN BILANGAN BULAT DI KELAS V SEKOLAH DASAR
}

\author{
Yeni Dwi Kurino \\ Yenidwi_kurino@yahoo.com \\ Universitas Majalengka
}

\begin{abstract}
ABSTRAK
Penelitian ini dilatarbelakangi oleh rendahnya hasil belajar siswa dala pembelajaran penjumlahan pengurangan bilangan bulat. Dalam penelitian ini pendekatan problem solving sebagai dasar pelaksanaan pembelajaran yang bedasarkan pada masalah. sebagai implementasinya diadakan penelitian tindakan kelas dengan topik pembelajaran operasi penjumlahan dan pengurangan bilangan bulat di kelas V SDN Munjul III, Kecamatan Majalengka, Kabupaten Majalengka. Metode yang digunakan adalah penelitian tindakan kelas, dalam pembelajaran pemecahan masalah. Tehnik pengumpulan data yang digunakan meliputi lembar observasi, pedoman wawancara, catatan lapangan, foto. Data yang diperoleh dideskripsikan kemudian dianalisis, direfleksi dengan menggunakan deskripsi kualitatif dan kuantitatif. Sebagai subjek penelitian adalah anak didik kelas V SDN Munjul III yang berjumlah 22 orang, 17 perempuan dan 5 laki-laki. Hasil penelitian dengan menggunakan pendekatan problem solving anak didik dapat belajar dengan baik terbukti dengan meningkatnya hasil belajar tentang operasi penjumlahan dan pengurangan bilangan bulat, Hal ini ditunjukan dengan adanya peningkatan dari sebelum pemberian tindakan hingga siklus II. pada siklus I tindakan I yang semula hasil tes siswa hanya 59,89\% meningkat sebanyak 5,36\% pada tindakan II menjadi 65,15\%. Pada siklus II tindakan I mengalami kenaikan sebanyak $15,79 \%$ dari sikus sebelumnya menjadi $76,94 \%$ kemudian meningkat sebanyak 3,27\% pada tindakan II menjadi 80,21\%/ Hasil penelitian pada siklus II dalam penelitian ini telah mencapai $80 \%$ yaitu sebesar 84,21 . Maka dengan demikian peneliti menyimpulkan bahwa penelitian ini telah berhasil. Maka dengan demikian Kesimpulannya dalam penelitian ini dikatakan berhasil, terbukti dengan adanya peningkatan dalam hasil belajar yang optimal, dalam pembelajaran melalui problem solving aktivitas anak didik meningkat terbukti dengan nilai rata-rata yang diperoleh naik. Saran dalam penelitian ini adalah untuk meningkatkan hasil belajar anak didik hendaknya guru kreatif, memahami karakteristik anak didik, dan memperhatikan sarana dan prasarana. Sebagai alternatif salah satu pembeajaran yang mendukung akan kreativitas anak maupun guru adalah pendekatan problem solving.
\end{abstract}

Kata kunci : problem solving, hasil belajar dan operasi penjumlahan dan pengurangan bilangan bulat 


\section{A. PENDAhuluAN}

Mata pelajaran matematika di Sekolah Dasar (SD) bertujuan agar anak didik mampu mengembangkan pengetahuan, dan keterampilan dasar matematika dalam kehidupan sehari-hari. Hasil kajian para guru di SD mengungkapkan adanya permasalahan dalam pembelajaran matematika, dimana anak didik merasa cemas jika berhadapan dengan matematika. Kecemasan terhadap matematika dapat diartikan sebagai perasaan takut atau tidak senang yang melanda anak didik, ketika ia sedang atau akan berhadapan dengan pelajaran matematika. Hal ini yang menjadikan keadaan seperti ini disebabkan oleh semakin tinggi jenjang pendidikan maka matematika akan semakin kompleks.

Adanya tidak senang pada diri anak didik terhadap mata pelajaran matematika, membawa dampak negatif pada kegairahan mereka untuk belajar. Hal ini mengakibatkan rendahnya tingkat penguasaan materi yang diajarkan. Banyak anak didik yang kelihatan murung tatkala sedang belajar matematika di kelas. Mereka tidak tahu mengapa harus belajar rumus ini atau rumus itu, mereka tidak tahu manfaatnya, mungkin tidak mengerti makna dari belajar matematika dalam kehidupan sehari-hari dengan apa yang telah dipelajari disekolah. Maka dari itu upaya yang dilakukan oleh seorang guru adalah harus mengadakan suatu penelitian mengenai pembelajaran matematika di sekolah dasar, selain dari pada itu guru juga harus meningkatkan keprofesionalannya misalnya melanjutkan sekolah kejenjang yang lebih tinggi sehingga memperoleh ilmu dan pengalaman yang lebih dalam yang berguna dalam pekerjaannya di lapangan.

Pada kenyataannya di lapangan, di SD Negeri Munjul IIIdalam pembelajaran matematika, guru kurang biasa menggunakan pendekatan atau metode Problem Solving (pemecahan masalah), sedangkan pendekatan problem solving mempunyai suatu kelebihan yaitu : menghubungkan pengajaran dengan kehidupan sehari-hari, karena masalah yang diangkat dalam kegiatan belajar mengajar diambil dari kehidupan anak didik sehari-hari, dapat merangsang kemampuan intelektual dan daya pikir anak didik, dapat melatih dan membiasakan anak didik untuk menghadapi dan memecahkan masalah secara cermat, mampu melatih anak didik untuk berpikir secara sistematis dan menghubungkannya dengan masalahmasalah lainnya, karena dalam kehidupan senantiasa dihadapkan pada masalahmasalah yang menuntut pemecahan secara sistematis. Hal ini sesuai dengan pendapat Gagne (Dahar, 1996 : 134) "kalau seorang anak didik dihadapkan pada suatu masalah, maka pada akhirnya mereka bukan hanya sekedar memecahkan masalah, tetapi belajar sesuatu yang baru". Berdasarkan kenyataan di lapangan, hal ini menuntut kepada tugas guru yang utama adalah mengajar, mendidik dan membimbing dengan tujuan akhir membentuk sikap dewasa yang siap hidup di lingkungan masyarakat. Oleh karena itu sebagai tenaga pengajar di SDN Munjul, saya akan melaksanakan penelitian di Kelas V SD, dengan mengunakan pendekatan problem solving dalam pokok bahasan penjumlahan dan pengurangan bilangan bulat, dengan tujuan dapat meningkatkan pemahaman akan bilangan bulat, aktivitas belajar dan hasil belajar anak didik. Selain dari pada itu peneliti akan memperbaiki kegiatan guru yang kurang biasa mengunakan pendekatan problem solving.

Matematika merupakan salah satu mata pelajaran yang memiliki kedudukan yang penting bagi perkembangan ilmu pengetahuan dan teknologi. Berdasarkan Permendiknas no 22 tahun 2006 :

Kemampuan bernalar merupakan salah satu dari sekian kecerdasan yang sangat 
penting dimiliki, dikuasai dan dikembangkan ketika akan mempelajari matematika, terlebih saat siswa dihadapkan pada masalah matematika yang harus diselesaikannya.

Sehubung dengan penyataan diatas, maka pembelajaran dengan menggunakan pendekatan problem solving dalam operasi penjumlahan dan pengurangan bilangan bulat, disesuaikan dengan kurikulum KTSP Matematika SD bahwa materi ini sebagai lanjutan dari kelas IV. Maka dari itu peneliti akan memperbaiki dan meneliti pembelajaran yang dilakukan di SDN Munjul III yang kurang biasa menggunakan problem solving dalam pembelajaran operasi penjumlahan dan pengurangan bilangan bulat.

Pendekatan Problem Solving adalah suatu cara penyajian bahan pelajaran dengan menjadikan masalah sebagai titik tolak pembahasan untuk dianalisis dan disintesis dalam usaha mencari pemecahan atau jawabannya oleh anak didik. Permasalahan itu dapat diajukan atau diberikan guru kepada anak didik, dari anak didik bersama guru, atau dari anak didik itu sendiri, yang kemudian dijadikan pembahasan dan dicari permaslahannya sebagai kegiatan-kegiatan belajar anak didik.

Problem solving berasal dari bahasa Inggris yang diartikan sebagai pemecahan masalah. Menurut Gagne (Rusyan, A.T, 2004:64) "kalau seorang peserta didik dihadapkan suatu masalah, maka pada akhirnya mereka bukan hanya sekedar memecahkan masalah tetapi belajar sesuatu yang baru". Oleh karena itu Pendekatan Problem Solving cocok untuk digunakan di Sekolah Dasar.

Problem Solving bukan suatu yang sederhana meskipun berkenaan dengan penerapan aturan-aturan belajar yang telah dipelahari sebelumnya. Problem solving juga menghasilkan suatu proses yang menghasilkan pelajaran baru, dimana peserta didik ditempatkan pada suatu masalah dan mereka mengingat aturanaturan yang diperoleh dalam upaya menemukan suatu solusi atau pemecahan masalah. Dalam proses berfikir anak mungkin mencoba sejumlah hipotesis dan menerapkan kemampuannya, bila mereka menemukan suatu kombinasi tertentu dari aturan-aturan dalam situasi yang cocok, maka mereka tidak hanya memecahkan masalah, tetapi juga telah mempelajari sesuatu yang baru.

Problem Solving memegang peranan penting agar pengajaran berjalan dengan fleksibel. Sehubungan dengan itu ditekankan perlunya pengajaran matematika dan berhitung dengan meningkatkan keterampilan memecahkan masalah sehingga anak didik dipersiapkan secara tepat untuk mernghadapi dunia yang ditandai oleh pertumbuhan dan komplekstisitas, perubahan yang serba cepat, dan ilmu pengetahuan yang sangat meluas. Sehubungan dengan itu perlu mengkaji Problem Solving yang relevansinya terhadap proses pendidikan. Di sisi lain dalam pemrosesan informasi pendekatan Problem Solving dapat membentuk kognisi-kognisi peserta secara kokoh terhadap suatu pemahaman dasar, berkenaan dengan tanggung jawab pemrosesan informasi tersebut jika pendekataan Problem Solving tersebut dilakukan seacara efektif.

Pendekatan Problem Solving ini dalam proses pembelajaran memungkinkan menghubungkan pengajaran dalam kehidupan sehari-hari, dapat merangsang kemampuan intelektual dan daya pikir anak, melatih membiasakan diri dalam menghadapi masalah.

Kelebihan dalam Pendekatan Problem Solving yang dapat peneliti sampaikan adalah menghubungkan pengajaran dengan kehidupan sehari-hari, karena masalah yang diangkat dalam kegiatan belajar mengajar diambil dari kehidupan anak didik sehari-hari, dapat merangsang kemampuan intelektual dan 
daya pikir peserta didik, dapat melatih dan membiasakan peserta didik untuk menghadapi dan memecahkan masalah secara cermat, mampu melatih peserta didik untuk berpikir secara sistematis dan menghubungkannya dengan masalahmasalah lainnya.

Adapun kekurangan Pendekatan Problem Solving yang peneliti sampaikan adalah setiap anak mempunyai kemampuan memecahkan maslah yang berbeda jadi sulit untuk menentukan masalah yang sesuai dengan berfikir setiap peserta didik, memerlukan waktu yang cukup lama kalau dilaksanakan sesuai langkah yang sistematis, Seringkali anak tidak dapat memecahkan masalah - masalah sendiri, atau bahkan anak tidak percaya diri sehingga memerlukan keterlibatam guru, masalah yang dijadikan dalam pembelajaran sering dibuat oleh guru, sehingga pelajaran kurang menarik, dalam pemecahan masalahnya guru sering menuntut agar cara pemecahan sama degan guru, menuntut anak tidak kreatif, pembelajaran menjadi membosankan karena bersipat monoton tidak ada perubahan dari tahun ketahun.

Langkah langkah pembelajaran dalam pendekatan Problem Solving menurut Polya ( Suryadi, Didi 2001 : 2) mengatakan bahwa :

solusi soal pemecahan masalah memuat empat langkah fase yaitu : memahami masalah, merencanakan penyelesaian, menyelesaikan masalah sesuai rencana dan melakukan pengecekan kembali terhadap semua langkah yang dikerjakan. Dengan cara seperti ini maka berbagai kesalahan yang tidak perlu dapat terkoreksi kembali sehingga siswa dapat sampai pada jawaban yang benar sesuai dengan masalah yang diberikan

Selain menurut Polya di atas, ada juga menurut para ahli mengemukakan berbagai langkah dalam melakukan Problem Solving, tapi pada hakikatnya sama. Menurut Davis Alexander (Rusyan,
2004 : 67) mengemukakan bahwa : 'langkah - langkah problem solving sebagai suatu seri, yang meliputi : Sensing Potensial Problem, Formulating Problem, Search For Solution, Trade Off among solution and initial selection, Implementasi and Evaluation'.

Pengertian dari langkah-langkah problem solving menurut Davis Alexander yang meliputi lima langkah adalah sebagai berikut :

a. Sensing Potensial Problem, dapat diartikan sebagai suatu kondisi dimana anak didik merasakan adanya masalahmasalah yang potensial, yang menuntut pemecahannya.

b. Formulating Problem, Suatu kondisi dimana suatu masalah dirasakan dan pada saaat itulah masalah siap untuk diformilasikan, biasanya difoemulasikan dalam bentuk pertanyaan.

c. Search For Solution, sewaktu masalah sudah diformulasikan, orang yang memecahkan masalah mengumpulkan informasi dari berbagai sumber untuk menemukan pemecahan masalah tersebut.Dengan menghubungkan data dan ide-idenya, maka orang yang melakukan pemecahan masalah membuat hipotesis pemecahan masalah untuk diujicobakan.

d. Trade-off Among Solution and Initial selection. Suatu kondisi dimana sewaktu semua pemecahan masalah itu sudah dikemukakan, tidak selalu semuanya adalah penting dan memungkinkan, mungkin hanya beberapa bagian dari pemecahan masalah itu terpakai.

e. Implementasi and Evaluasi, Setelah suatu masalah di dapatkan, maka yang perlu adalah bagaimana implemntasi pemecahan masalah tersebut, mungkin pada situasi yang lain, dan kemudian dievaluasi apakah pemecahan masalah yang dilakukan sudah berlaku umum. 


\section{METODOLOGI}

Metode yang digunakan dalam penelitian ini PTK (Penelitian Tindakan Kelas). Dengan teknik tersebut peneliti dapat mengetahui secara sistematis proses pembelajaran di kelas. Peneliti juga mendapat kesempatan untuk merencanakan dan melaksanakan gagasan untuk meningkatkan kemampuan anak didik.

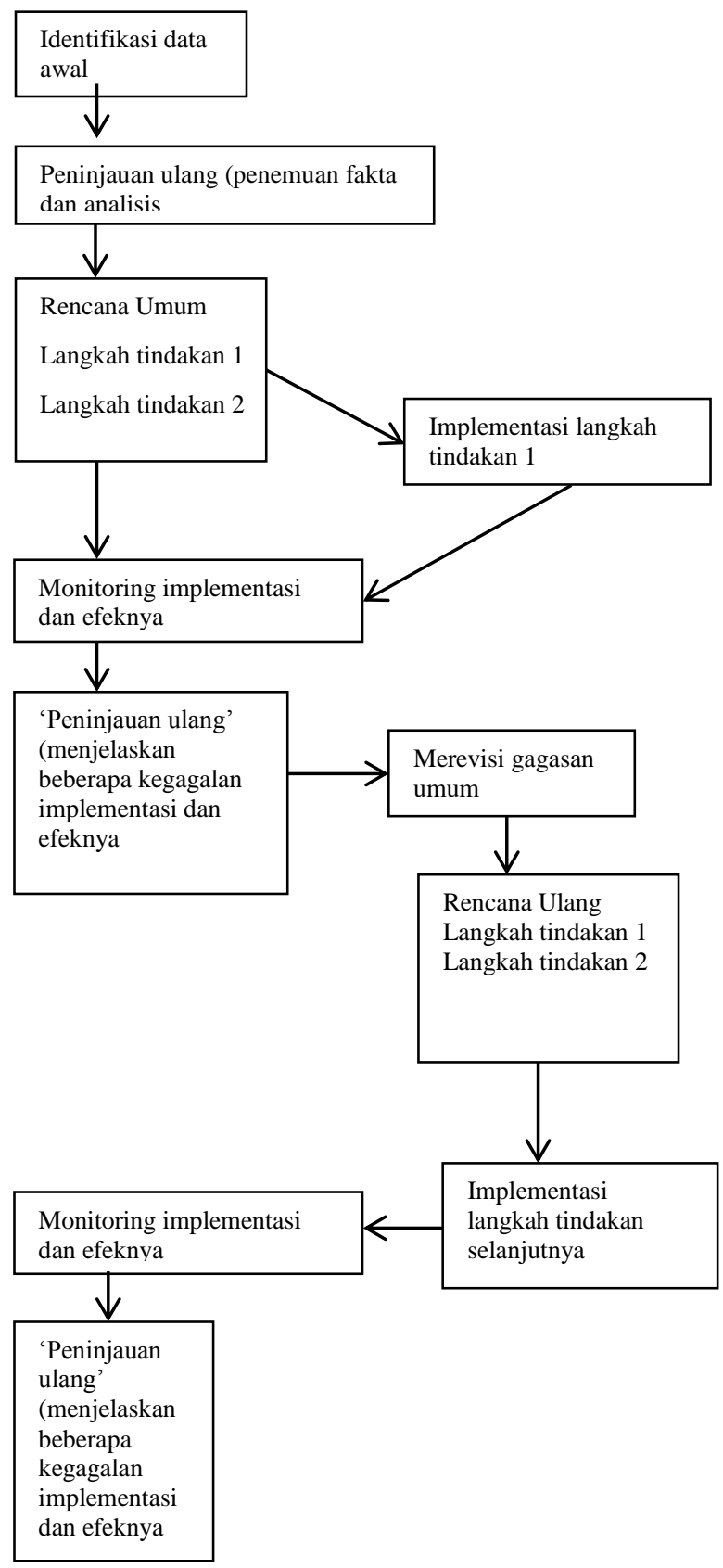

Gambar 1

Alur PTK Model John Elliot

(Novianti, 2013:54)
Dalam penelitian ini dilakukan penelitian kelas yang menekankan adanya tindakan-tindakan tertentu dalam upaya membantu guru dalam menggunakan pendekatan pada proses pembelajaran matematika. Penggunaan pendekatan Problem Solving dalam proses pembelajaran diharapkan dapat meningkatkan pemahaman, aktivitas serta hasil belajar siswa kelas V SD dalam pembelajaran operasi penjumlahan dan pengurangan bilangan bulat.

\section{HASIL DAN PEMBAHASAN}

Berdasarkan Kondisi awal yang dilakukan pada siswa kelas V di SDN Munjul1 pada pembelajaran matematika dapat diketahui bahwa kemampuan pembelajaran penjumlahan dan pengurangan bilangan bulat siswa masih rendah.

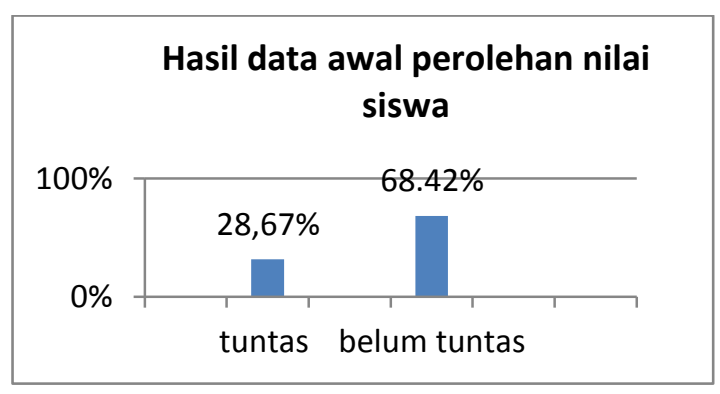

Gambar 1

Hasil tes belajar siswa mengalami peningkatan. Hal ini dapat dilihat dari gambaran lengkap berkaitan dengan tes hasil belajar siswa selama kegiatan pembelajaran dalam penelitian yang peneliti laksanakan dapat dilihat pada tabel sebagai berikut:

Tabel 1

Hasil tes siswa

\begin{tabular}{|l|l|l|l|}
\hline \multicolumn{2}{|l|}{ Siklus I } & \multicolumn{3}{l|}{ Siklus II } \\
\hline T1 & T2 & T1 & T2 \\
\hline $59,79 \%$ & $65,15 \%$ & $59,79 \%$ & $65,15 \%$ \\
\hline
\end{tabular}

Dari tabel 1 dapat kita ketahui bahwa terdapat peningkatan tes siswa dalam proses pembelajaran pada siklus I tindakan I yang semula hasil tes siswa hanya 
$59,89 \%$ meningkat sebanyak $5,36 \%$ pada tindakan II menjadi $65,15 \%$. Pada siklus II tindakan I mengalami kenaikan sebanyak $15,79 \%$ dari sikus sebelumnya menjadi $76,94 \%$ kemudian meningkat sebanyak $3,27 \%$ pada tindakan II menjadi $80,21 \%$ / Hasil penelitian pada siklus II dalam penelitian ini telah mencapai $80 \%$ yaitu sebesar 84,21. Maka dengan demikian peneliti menyimpulkan bahwa penelitian ini telah berhasil.

Gambaran grafik hasil tes siswa dalam proses pembelajaran dapat dilihat pada grafik berikut:

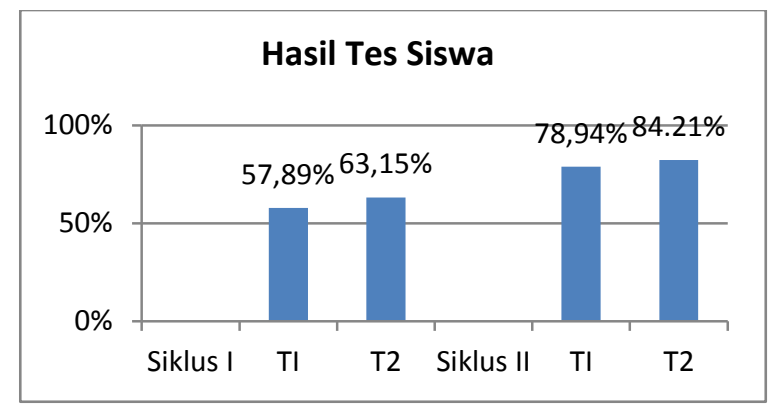

Gambar 2

Grafik hasil tes siswa

Berdasarkan data di atas, hasil tes siswa pada setiap siklus dan setiap tindakan mengalami peningkatan. Perolehan hasil siswa pada siklus I tindakan I sebesar $57,89 \%$ meningkat menjadi $63,15 \%$ pada siklus I tindakan II. Sedangkan pada siklus II tindakan II perolehan hasil siswa sebesar $78,94 \%$ menjadi $84,21 \%$ pada siklus II tindakan II. Hal ini membuktikan bahwa tingkat penalaran siswa selama proses pembelajaran telah mengalami peningkatan.

1. Penerapan Model Pembelajaran problem solving

Pada Problem solving guru berperan sebagai pembimbing dalam kegiatan pembelajaran, pertanyaan, mengeksplorasi pengetahuan siswa, menyediakan fasilitas yang diperlukan siswa dan memberikan dukungan dalam upaya meningkatkan perkembangan intelektual siswa sehingga struktuk kognitif siswa dapat terbentuk dengan baik.
Maka berdasarkan pendapat di atas, model problem solving diorientasikan untuk meningkatkan hasil belajar siswa dengan cara meminta siswa melaksanakan memecahkan masalah dan memberikan penjelasan agar struktuk kognitif siswa dapat terbentuk dengan baik.

Adapun hasil observasi selama proses pembelajaran baik pada kegiatan siswa maupun kinerja guru mengalami peningkatan pada setiap siklus. Untuk lebih jelasnya, peningkatan kegiatan siswa dan kinerja guru dalam pembelajaran dapat dilihat pada tabel berikut ini :

\section{Tabel 2}

Hasil observasi kegiatan siswa

\begin{tabular}{|l|l|l|l|}
\hline \multicolumn{2}{|l|}{ Siklus I } & \multicolumn{2}{l|}{ Siklus II } \\
\hline T1 & T2 & T1 & T2 \\
\hline 75 & 82,14 & 92,85 & 96,42 \\
$\%$ & $\%$ & $\%$ & $\%$ \\
\hline
\end{tabular}

Berdasarkan tabel 2 hasil observasi kegiatan siswa mengalami peningkatan di setiap siklus dan tindakannya. Pada siklus I tindakan I hasil observasi siswa sebesar $75 \%$ naik sebesar $7,14 \%$ pada tindakan II sehingga menjadi $82,14 \%$. Pada siklus II tindakan I mengalami kenaikan sebanyak $10,71 \%$ dari sikus sebelumnya menjadi $92,85 \%$ dan naik sebesar $3,57 \%$ pada tindakan II sehingga menjadi 96,42\%.

Gambaran grafik hasil tes siswa dalam proses pembelajaran dapat dilihat pada grafik berikut:

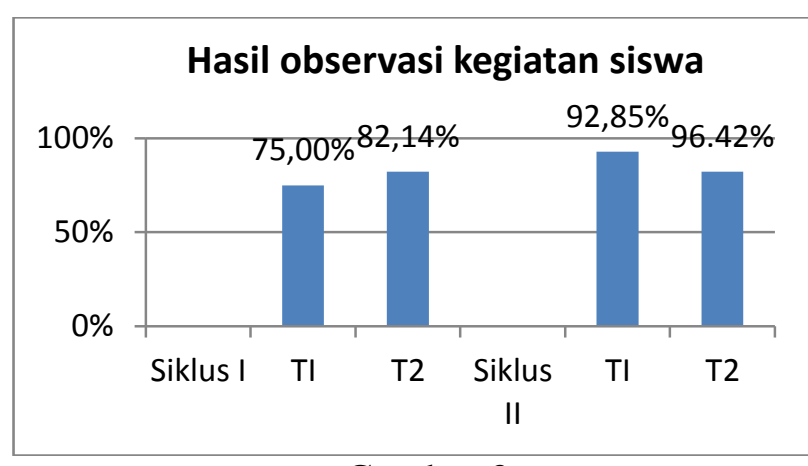

Gambar 3

Hasil observasi kegiatan siswa 
Berdasarkan data di atas, hasil observasi kegiatan siswa selama proses pembelajaran pada setiap siklus dan setiap tindakan mengalami peningkatan. Perolehan observasi siswa pada siklus I tindakan I sebesar $75 \%$ meningkat menjadi $82,14 \%$ pada siklus I tindakan II. Sedangkan pada siklus II tindakan II perolehan observasi siswa sebesar $92,85 \%$ menjadi $96,42 \%$ pada siklus II tindakan II.

Pada siklus I penyampaian materi dan upaya guru dalam memancing kemampuan pembelajaran penjumlahan dan pengurangan bilangan bulat siswa belum maksimal. Sehingga guru melakukan perbaikan pada tindakan selanjutnya. Pada siklus II guru sudah mengalami peningkatan dalam proses pembelajaran. hanya saja guru perlu memberikan tindak lanjut pada siswa untuk memaksimalkan hasil belajar siswa. Adapun untuk lebih jelasnya peningkatan kinerja guru dalam melakukan pembelajaran dapat dilihat pada tabel berikut ini:

Tabel 3

Hasil observasi kinerja guru

\begin{tabular}{|l|l|l|l|}
\hline \multicolumn{2}{|l|}{ Siklus I } & \multicolumn{2}{l|}{ Siklus II } \\
\hline T1 & T2 & T1 & T2 \\
\hline $75 \%$ & $78,57 \%$ & $75 \%$ & $78,57 \%$ \\
\hline
\end{tabular}

Berdasarkan tabel 3, hasil observasi kinerja guru mengalami peningkatan di setiap siklus dan tindakannya. Pada siklus I tindakan I hasil observasi kinerja guru sebesar $75 \%$ naik sebesar $3,57 \%$ pada tindakan II sehingga menjadi 78,57\%. Pada siklus II tindakan I mengalami kenaikan sebanyak $3,71 \%$ dari sikus sebelumnya menjadi $89,28 \%$ dan naik sebesar $7,14 \%$ pada tindakan II sehingga menjadi 96,42\%.

Gambaran grafik hasil observasi guru dalam proses pembelajaran dapat dilihat pada grafik berikut:

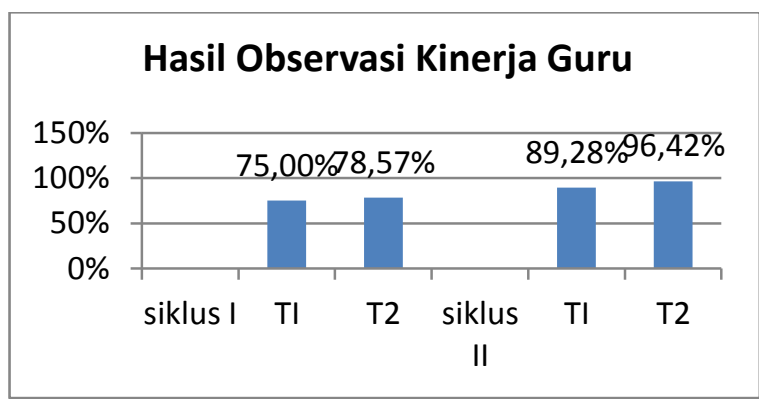

Gambar 5

Grafik hasil observasi kinerja guru

Berdasarkan data di atas, hasil observasi kinerja guru selama proses pembelajaran mengalami peningkatan dalam setiap siklusnya. Perolehan persentase hasil observasi guru pada siklus I tindakan I sebesar $75 \%$ menjadi $78,57 \%$ pada siklus I tindakan II. Sedangkan pada siklus II tindakan I hasil observasi guru semula sebesar 89,28\% mengalami peningkatan pada siklus II tindakan II menjadi $96,42 \%$.

Adapun hasil observasi siswa selama proses pembelajaran mengalami peningkatan pada setiap siklusnya.

2. Peningkatan hasil belajar Siswa dengan Penerapan Model Pembelajran problem solving

Perkembangan berpikir seorang siswa bergerak dari kegiatan berpikir konkret menuju berpikir abstrak. Seorang guru perlu memahami kemampuan berpikir siswa sehingga tidak memaksakan materimateri pelajaran yang tingkat kesukarannya tidak sesuai dengan kemampuan siswa. Apabila hal ini terjadi maka siswa mengalami kesukaran untuk mencerna gagasan-gagasan dari materi pelajaran yang diberikan, maka usaha guru untuk membelajarkan siswa bisa disebut gagal. Disini penting bahwa setiap siswa memiliki hasil belajar siswa.. Karin Brodie (Shadiq, 2004:5) menyatakan bahwa, "Mathematical reasoning is reasoning about and with the object of mathematics." Pernyataan tersebut dapat diartikan bahwa penalaran matematis 
adalah penalaran mengenai objek matematika.

Peningkatan hasil belajar siswa dengan penerapan Problem solving mengalami peningkatan pada setiap siklusnya. Hal ini dilihat dari hasil tes belajar siswa selama pembelajaran.

Gambaran grafik nilai perbandingan hasil belajar siswa pada data awal, siklus I dan siklus II dapat pula dilihat pada grafik berikut:

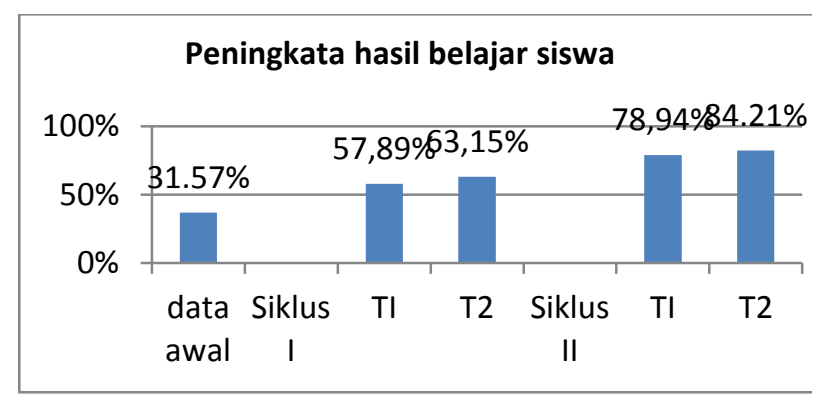

Gambar 6

Grafik hasil belajar siswa

Dari data di atas dapat kita ketahui bahwa hasil belajar siswa pada data awal hanya mencapai rata-rata 67,63 dengan persentase ketuntasan $31,57 \%$. Pada siklus I tindakan I hanya mencapai rata-rata 73,47 dengan persentase ketuntasan belajar sebesar $57,89 \%$. Pada siklus 1 tindakan II mengalami peningkatan dengan rata-rata 75,10 dengan persentase ketuntasan belajar sebesar $63,15 \%$. Pada siklus II tindakan I mengalami kenaikan yang cukup signifikan dengan nilai rata-rata 79,47 dan persentase ketuntasan belajar mencapai 78,94\%. Pada akhir siklus yaitu pada siklus II tindakan II terdapat peningkatan hasil belajar siswa hingga mencapai rata -rata 81,15 dengan pencapaian ketuntasan belajar mencapai $84,21 \%$.

\section{SIMPULAN DAN SARAN}

Berdasarkan hasil uraian dari pembahasan dan analisis data sebelumnya maka dalam penelitian ini peneliti dapat mengambil kesimpulan penelitian sebagai berikut:
1. Dengan menggunakan problem solving dapat meningkatkan hasil belajar siswa dalam pembelajaran matematika, tentang operasi penjumlahan dan pengurangan bilangan bulat. Peningkatan hasil belajar siswa tersebut dibuktikan dengan data mulai dari data awal sampai siklus II.

2. Melalui pendekatan problem solving, dapat diketahui gambaran aktivitas belajar yang menekankan pada proses pemecahan masalah, hal ini dibuktikan dengan adanya peningkatan aktivitas anak secara bertahap, dari aktivitas yang sederhana samapi ke aktivitas yang kompleks sehingga membentuk sikap yang dewasa dan disiplin, dimana dalam pembelajarannya meliputi aktivitas belajar kelompok yang terdiri dari keaktifan, ketelitian, kerja sama dan ketepatan dalam memecahkan suatu masalah. Dengan menggunakan pendekatan problem solving, dimana hasil belajar anak didik berdasarkan penelitian ini, pada setiap siklus dan tindakan ratarata terus bertambah besar dan variansinya turun (rendah), hal ini membuktikan bahwa penyebaran skor atau hasil belajar lebih merata dengan besar nilai di atas rata-rata. Oleh karena itu pembelajaran melalui pendekatan problem solving dapat meningkatkan hasil belajar anak didik secara optimal.

Melalui hasil penelitian yang dilakukan dan atas dasar kesimpulan yang yang telah paparkan, penulis memberikan saran yang diharapkan dapat dipertimbangkan oleh pembaca dalam memberikan materi mengenai operasi penjumlahan dan pengurangan bilangan. Adapun saran yang peneliti sampaikan adalah sebagai berikut :

1. Untuk meningkatkan hasil belajar dalam pembelajaran matematika tentang operasi penjumlahan dan pengurangan bilangan bulat, guru hendaknya menggunakan pendekatan problem solving (pemecahan masalah) agar anak terbiasa dalam memecahkan 
masalah, karena pendekatan ini mempunyai kelebihan atas kreativitas anak.

2. Dalam meningkatkan aktivitas belajar anak didik, guru seharusnya memperhatikan perkembangan anak didik, memahami karakteristik individu yang sangat beragam, serta harus ditunjang dengan sarana dan prasarana yang cukup dan banyak melakukan penelitian tindakan kelas, agar terciptanya pembelajaran yang aktif kreatif dan menyenangkan.

3. Dalam meningkatkan hasil belajar anak didik yang berkualitas guru hendaknya dalam memberikan materi harus efektif dan efesien serta dalam membuat soal harus menjadi alat ukur yang handal, yang bervaliditas yang disesuaikan dengan keseimbangan antara aspek kognitif, afektif dan psikomotor.

4. Penelitian ini dijadikan sebagai model atau contoh sehinga dapat memberi masukan umumnya kepada guru-guru SD dan khususnya guru kelas V tentang pembelajaran Matematika..

\section{DAFTAR PUSTAKA}

Arikunto, S. (2002). Prosedur Penelitian Suatu Pendekatan Praktek. Jakarta: Rineka Cipta.

Depdiknas. (2003). Undang-undang No 20 Tahun 2003, tentang Sistem Pendidikan Nasional. Jakarta: Depdiknas. (2004). Peraturan Dirjen Dikdasmen No 506/C/PP/2004 tanggal 11 November 2004 tentang Penilaian Perkembangan anak Didik Sekolah Menengah Pertama (SMP). Jakarta: Dirjen Dikdasmen Depdiknas.

Aqib, Zaenal. (2006). Penelitian Tindakan Kelas Untuk Guru. Majalengka : Yrama Widya.

Dahar, Ratna W. (1996). Teori-Teori Belajar. Jakarta : Erlangga
Darhim. (2004). Kurikulum Berbasis Kompetensi . GBPP Matematika. Jakarta : Depdikbud.

Engkoswara, et al. (1996). Pedoman Penyusunan Karya Ilmiah Untuk Angka Kredit Guru SD. Majalengka : Karang Sewu.

Fitriyah, Munawati. (2004). Matematika Progresif Untuk Kelas 5 SD. Jakarta : Widya Utama.

Kartadinata, Sunaryo. (1992). Tehnik Pengukuran dan Penilaian Hasil Belajar. Majalengka: Andira.

Komariah. (2003). Pengembangan Kemampuan Pemecahan Masalah Matematika Siswa Sekolah Dasar Melalui Kegiatan Kelompok. Majalengka

Mukhtar, dan Yamin, M. ( 2005 ). Metode Pembelajran Yang berhasil. Jakarta : PT. Nimas Multima.

Mulyasa, E. (2000). Cara Membuat Alat Peraga Sederhana Bagi Guru Sekolah Dasar. Majalengka : GV Geger Sunten.

Moesono, Djoko. dan M, Amin S. (1994). Matematika 5 Mari Berhitung Jakarta : Perum Balai Pustaka

Rachmat, Dkk. ( 2004 ). Belajar Matematika Dengan Orientasi Penemuan \& Pemecahan Masalah Jilid 5 A. Majalengka : PT Sarana Panca Karya Nusa.

Rakhmat, C dan Solehudin, M. ( 2006 ). Pengukuran dan Penilaian Hasil Belajar. Majalengka : Andira.

Ruseffendi, E.T, et al. (1990). Pengajaran Matematika Modern dan Masa Kini. 
Majalengka : Tarsito.

Rusyan, A,T. (2004). Pedoman Mengajar Matematika Berdasarkan Kurikulum Berbasis Kompetensi. Jakarta : Intimedia

Sagala, Syaepul (2006). Konsep dan Makna Pembelajaran. Majalengka : Alfabeta.

Suharsimi, A. (1999). Dasar-Dasar Evaluasi Pendidikan. IKIP Yogyakarta: Bumi Aksara.

Soedarsono, FX. (1996). Pedoman Pelaksanaan Penelitian Tindakan Kelas Bagian Ke dua. IKIP Yogyakarta: Depdikbud.

Sudjana, N. (1996). Metode Statistika. Majalengka : Tarsito.

Suherman AS, U. (2000). Memahami Karakteristik Individu. Majalengka : Publikasi Jurusan Psikologi Pendidikan dan Bimbingan.

Suryadi, Didi (2001). Pembelajaran Pemecahan Masalah Matematika di Sekolah Dasar. UPI Majalengka : Depdikbud
Surya, M, ( 2003 ). Psikologi Pembelajaran dan Pengajaran. Majalengka : Yayasan Bhakti Winaya.

Sutawidjaja, dkk.. (1991) Pendidikan Matematika III. Jakarta : Depdikbud.

Suyanto, (1996). Pedoman Pelaksanaan Penelitian Tindakan Kelas Bagian Ke satu. Yogyakarta: Depdikbud.

Syamsuddin Makmun, T. ( 2000). Psikologi Kependidikan Perangkat sistem Pengajaran Modul. Majalengka ; PT Remaja Rosdakarya Majalengka.

Undang, G (1997). Peningkatan Mutu Proses Belajar Mengajar di Sekolah Dasar. Majalengka : Siger Tengah.

Windayana, H. et al. (2007). Konsep DasarMatematika. Majalengka : UPI Kampus Cibiru

Windayana, H. et al. (2006). Modul Pendidikan Matematika I. Majalengka : UPI Kampus Cibiru. 